\title{
ROLE OF HOPS-PLANT CARBON DIOXIDE PREPARATIONS IN ELIMINATION OF COMPLICATIONS OF WOUND PROCESSES
}

\author{
РОЛЬ ПРЕПАРАТІВ ХМЕЛЮ ВУГЛЕКИСЛОТНОГО \\ В УСУНЕННІ УСКЛАДНЕНЬ РАНОВОГО ПРОЦЕСУ
}

\author{
Khrystian Gennadiy ${ }^{1}$ \\ Torianyk Inna ${ }^{2}$ \\ Nevmrgitscky Vitaliy ${ }^{3}$
}

DOI: https://doi.org/10.30525/978-9934-571-78-7_49

Abstract. Nowadays, the world's greatest hops producers are Germany, Poland, the U.S.A, Czech Republic, Ukraine, Russia. The use of hops as a medicinal plant has more than $2000 \mathrm{y}$ of history. The ancient healers used hops against leprosy, foot odor, constipation, and for blood purification. One of the most valuable scientific manuscripts of the 15th century, the Garden of Health, describes the effect of hops in combating ear infections. In the 16 th century, the German botanist Hieronymus Bock documented the 1st application of hop in gynecology, Paracelsus used the hops plant against indigestion, and the Italian doctor Matthiolus mentioned its diuretic and bile-increasing effects (Biendl, 2009; Koetter and Biendl, 2010). From the 19th century, phytotherapy has focused on the effects of hop against sleeplessness. The neurotropic effect of galenic preparations from cones of hop is associated with the presence of lupulin, which has a calming effect on the nervous system. Anti-inflammatory, analgesic, bactericidal and antiallergic properties of herbal preparations of the plant determine their therapeutic effectiveness in diseases of the skin and mucous membranes, accompanied by inflammatory lesions, allergic manifestations, itching and other symptoms. The purpose of the

\footnotetext{
${ }^{1} \mathrm{PhD}$, Research Scientists at Laboratory of Antimicrobial Agent's,

State Institution «I. Mechnikov Institute of Microbiology

and Immunology National Academy of Medical Sciences of Ukraine», Ukraine

${ }^{2} \mathrm{PhD}$, Leader Research Scientists at Laboratory of Viral Infection,

State Institution «I. Mechnikov Institute of Microbiology

and Immunology National Academy of Medical Sciences of Ukraine», Ukraine

${ }^{3}$ Postgraduate Student at Laboratory of Antimicrobial Agent's,

State Institution «I. Mechnikov Institute of Microbiology

and Immunology National Academy of Medical Sciences of Ukraine», Ukraine
} 
planned study role of hops preparations in elimination of complications of wound processes (after military, diabetic, industrial, household injuries). The research methodology was based on a complex of biochemical, biophysical, microbiological, clinical, retrospective methods. It was established, that for local treatment of suppurative inflammatory processes of the skin, widely used multicomponent preparations of hops carbon dioxide ointments on a water-soluble base, having antimicrobial activity, corresponding to the phases of the wound process, exhibiting the necessary osmotic effect. On models of wounds and thermal burns of the skin it was proved the stimulating effect of the liniment with the extracts of hops preparations and ointment based on extract of garlic bulbs on reparative tissue regeneration has been established. The expressed antimicrobial activity of the ointment with an extract of hops, which containing essential oils, stearins has been proved. The key to rapid healing of wounds was a differential approach to their treatment, depending on the stage of the wound process and the etiological factor. One of contributes to the healing of wounds maintaining a proper level of moisture of regenerating tissues. So, for this at present hops- plant ointments are made on a hydrophilic basis.

\section{1. Ветуп}

На сьогоднішній день в Україні проблема ранової патології займає одне із провідних місць серед науково-дослідницьких пріоритетів [1, p. 289-292]. Шляхів і джерел виникнення ранової інфекції описано чимало. Проте, головними із них були і залишаються прямий, контактний, повітряно-крапельний, а також ендогенне інфікування. Ранові інфекції прийнято диференціювати на декілька великих груп гострих і хронічних, позалікарняних та нозокоміальних. Нозокоміальні ранові інфекції це нагальна проблема, що гостро постається перед фахівцями хірургічних стаціонарів. Особливістю нозокоміальних ранових інфекцій є висока частота резистентних до багатьох антибіотиків збудників, що, в свою чергу, визначає особливість лікування [4, р. 599-608; 9, p. 32-37; 12, p. 3-12].

В цілому, переважаючими збудниками є грампозитивні коки, серед них - S. aureus i коагулазонегативні стафілококи. Джерелом інфекції можуть бути як шкіра самого хворого (транзіторная - S. aureus i облігатна флора), так і екзогенні джерела (наприклад, резервуаром $\mathrm{S}$. aureus або S. pyogenes $є$ медичні працівники або хворію. Внутріш- 
ньогоспітальне зараження S. aureus пояснюється, зокрема, колонізації верхніх дихальних шляхів і, отже, аерогенної дисемінацію). Актуальною проблемою залишається широке поширення ранових інфекцій, особливо серед опікових хворих, коли нозологію спричиняють групи MRSA [3, p. 116-123; 20, p. 449-450; 21, p. 598-602].

Примітно, що серед всіх нозокоміальних інфекцій, викликаних грамнегативними збудниками, на частку інфекцій шкіри і м'яких тканин приходиться 33\% [3, p. 116-123]. Грамнегативні бактерії - найважливіші збудники ранової інфекції в абдомінальній хірургії, гінекології, онкології і акушерстві; увагу заслуговують представники Enterobacteriaceae - E. coli, Enterobacter spp., Proteus spp., Acinetobacter spp., а також неспороутворюючі грамнегативні анаероби - Pseudomonas aeruginosa, Klebsiella spp. [16, p. 292-298; 17, p. 712-719; 18, p. 469-480]. Резервуари полірезістентних грамнегативних бактерий - опікові відділення, відділення гнійної хірургії, відділення реанімації та інтенсивної терапії. Особливе ставлення склалося до представників Bacteroides spp., а саме до Bacteroides fragilis. Ці анаеробні грамнегативні бактерії виявляють порівняно низьку вірулентність, але, будучи складовою полімікробної флори, разом 3 аеробними бактеріями демонструють виражений синергізм [16, р. 292-299; 20, р. 449-450].

В цілому, для етіології нозокоміальної ранової інфекції характерний певний взаємозв'язок з мікробною флорою відділення, де знаходиться хворий. Останній факт пояснюється ймовірністю потрапляння будь-якого мікроорганізму до рани, що робить його потенційним збудником захворювання.

Етіологія інфекційних ускладнень ран, отриманих в побуті, на виробництві, діабетичних, виниклих випадково у разі вуличної патології, як наслідок бойової травми [2, р. 892-899; 13, p. 45-61; 9, р. 32-37; 1, p. 289-292]) різноманітна і залежить від механізму травми, обставин травми, часу, що пройшов з моменту поранення, видів і обсягів хірургічної допомоги, яка була надана потерпілому та ін. При первинної обробці в посівах зі свіжих ран в переважній більшості випадків висіваються коки в основному, Staphylococcus spp. Достовірно встановлено, що в процесі лікування відбувається значна зміна характеру ранової мікрофлори; в основному спостерігається зміщення від домінування грампозитивних коків до грамнегативних аеробів [20, р. 449-450; 21, p. 598-602]. Таким чином, збудниками гнійної інфекції травматичних ран $є$ не «вулична» флора, 
що потрапила в рану при бактеріальному забрудненні, а госпітальна, яка проникає при недотриманні правил асептики в ході хірургічної обробці, виконання перев'язок тощо. Не можна недооцінювати грампозитивні коки i, перш за за все, S. aureus, оскільки в останній час позалікарняних випадки інфекцій, викликаних метіціллінрезістентним стафілококком, зустрічаються все частіше. Останнє пояснюється активністю основних дієвих анти-MRSA антибіотиків, що являються прерогативою спеціалізованих стаціонарів та унеможливлюють сам факт формування екологічних ніш $з$ подальшим широким поширенням зазначених штамів. Фахівцями доведено, що відсутність такого рівня препаратів сприяє наявній, реальній загрозі періодичних спалахів інфекцій м'яких тканин. Добре відомо, що у разі появи некротизованих тканин, порожнин, заповнених кров'ю або ексудатом, в асоціаціях бактерій превалюючи місце посідають анаероби, головним чином, Bacteroides fragilis i Bacteroides spp., а також Fusobacterium spp. і грампозитивні анаеробні коки, в основному Peptostreptococcus spp. і Peptococcus spp. Саме вони визначають розвиток важких некротизуючих форм ранової інфекції за умов аеробно-анаеробних асоціацій. Слід також пам'ятати, що зазначені факти обумовлюють також високий економічний сенс превентивних щодо ранової інфекції заходів [14, р. 189-194].

\section{2. Ранова інфекція як ускладнення раневого процесу. Перспективи усунення ранового процесу}

Ранова інфекція як форма ускладнення ранового процесу, обумовлена розвитком патогенної мікрофлори у безпосередньому просторі порожнин будь-яких ран. За цим слід пам'ятати, що всі хірургічні рани, в тому числі і післяопераційні, - чи то у загальній хірургії, чи то у травматології, нейро-, судинній хірургії вважаються первинно забрудненими, оскільки певна кількість мікробів потрапляє на поверхню рани $з$ повітря навіть у разі бездоганного дотримання правил асептики та антисептики [8, р. 5-12; 45-63; 81-89; 10, p. 317-323; 11, p. 17-22]. Випадкові рани забруднені у більшій мірі, тому в таких випадках джерелом інфекції, зазвичай, є первинне мікробне забруднення. При операційних ранах на перший план виступає ендогенне (з внутрішнього середовища організму) або внутрішньогоспітальне (вторинне) інфікування. У більшості випадків збудником інфекції в випадкових ранах стає стафілокок. Подекуди у якості основного збудника виступає 
протей, кишкова і синьогнійна паличка. У 0,1\% випадків зустрічається анаеробна інфекція. Через кілька днів перебування в стаціонарі флора змінюється, в рані починають переважати стійкі до антибактеріальної терапії грамнегативні бактерії, які зазвичай стають причиною розвитку ранової інфекції при вторинному інфікуванні як випадкових, так і операційних ран [10, р. 317-323; 15, р. 615-622].

Здатність мікробів викликати хірургічну (ранову) інфекцію зумовлюється їх кількісними і якісними особливостями, серед яких визначальне значення належить дозі і патогенності. Вважається, що наявність в рані до 1 млн. мікробних тіл на один грам тканини, спричиняє розвиток місцевого нагнійного процесу.

Інфекційні ускладнення ран - приєднання специфічної ранової інфекції: правця, анаеробної інфекції, сказу, дифтерії ран - зустрічалися часто і значно погіршують наслідки поранень. Зростає частота інфекційних ускладнень у хірургії мирного часу: нагноєння «чистих» операційних ран досягає 5\%, забруднених - 20-30\%; як причина смерті в післяопераційний період інфекційні ускладнення спостерігааться в $25 \%$ хворих [9, р. 32-37].

Розробка клінічного алгоритму лікування ран в залежності від фаз ранового процесу $є$ актуальною проблемою сучасної медицини хірургії. Використання широкого спектру медикаментозних засобів для місцевого лікування ран не завжди призводить до бажаного результату. Для вирішення цієї проблеми велике практичне значення має впровадження у клініку нових засобів для лікування ранової інфекції, що направлені на пригнічення біогенної мікрофлори, підвищення імунної резистентності тканин та нормалізацію в них метаболічних процесів. Ефективне лікування ран і профілактика ранових інфекційних ускладнень повинно базуватися не тільки на обгрунтованих клініко-лабораторних і патогенетичних принципах, але і на фармакологічних властивостях препаратів (урахування властивостей діючої речовини, іiі медикаментозної форми, сорбційних характеристик тощо) i їх диференційованого використання. Диференційований підбір оптимальних засобів місцевого лікування в залежності від стадії ранового процесу, його особливостей і ускладнень істотно впливає на терміни, очищення та грануляцію тканин. Провідне місце в терапії ранових пошкоджень шкіри надається засобам для зовнішнього застосування у формі мазей, що використовують під пов'язкою. Маркетинговими дослідженнями номенклатури дерматологічних 
м'яких лікарських засобів (МЛЗ), які представлені на фармацевтичному ринку України, встановлено, що асортимент МЛЗ, які застосовують для місцевого лікування ранових ушкоджень та виразок з урахуванням лікарської форми та виробника, становить 259 торгових марок та окремих лікарських елементів. Препарати для лікування ран I фази ранового процесу є як однокомпонентними так і комбінованими, виготовлені на гідрофобних, гідрофільних і емульсійних основах та мають ряд недоліків і переваг. Гідрофобні основи перешкоджають вивільненню лікарської субстанції і проникненню іiі в глиб тканин, порушують відтік ранового вмісту та герметизацію рани. В той час як гідрофільні основи створюють осмотичну рівновагу протягом тривалого часу, запобігають зневодненню тканин рани, сприяють вивільненню активних інгредієнтів з основи і їх проникненню в тканини, пов'язують рановий вміст. Монопрепарати мають недоліки через одну спрямованість дії - протимікробну або протизапальну або дегідратуючу, вони приймають участь в процесах запобігання бактеріальній адгезії, механізмах біоконтролю за збудниками ранової інфекції, тощо [4, р. 599-610; 5, р. 1195-1206; 6, p. 425-433]. Комбіновані ж препарати надають можливість одночасного впливу на різні ланки ранового процесу [3, p. 116-123].

У хірургії застосовують різні мазі на жировій основі: мазь Вишневського, синтоміцинова емульсія, мазі з антибіотиками (тетрациклінова, неоміцинова та ін.). Ці мазі гідрофобні, тобто не вбирають вологу. 3 цієї причини тампони, просочені цими мазями, не забезпечують відтоку ранового секрету, стають тільки пробкою. У той же час антибіотики, що містяться в складі мазей, не звільняються з композицій мазей і не надають достатньої антимікробної дії.

На теперішній час для місцевого лікування гнійно-запальних процесів шкіри широке застосування знайшли багатокомпонентні мазі на водорозчинній основі, що володіють антимікробною активністю, відповідні фазам ранового процесу, що проявляють необхідний осмотичний ефект. Однак результати ряду рандомізованих досліджень, які проводили оцінку антимікробної активності мазей, демонструють обмеженість вибору останніх щодо штамів MRSA. Для лікування гнійно-запальних процесів шкіри використовуються препарати комплексної сполуки йоду з полівінілпіролідоном (йодопиридонова мазь 1\%, Йодометриксид), проте дані про їх бактерицидної активності в відношення MRSA суперечливі. 
В той час як сполуки срібла і сульфатіазолу (Аргедин, Аргосульфан), завдяки антимікробним властивостям, проявляють токсичну дію щодо широкого спектра патогенних бактерій, вірусів, грибів внаслідок взаємодії $з$ нуклеїновими кислотами, пошкодження структурних білків мембран і клітинної стінки. Як показано в дослідженні in vitro, сполуки срібла і сульфаніламідів ефективні відносно 50 штамів MRSA. Одним $з$ факторів, що підвищують стійкість бактерій до несприятливої дії навколишнього середовища, є формування специфічно організованих (створених) біоплівок на поверхні шкіри. Біоплівка має складну структуру, а патогенні мікроорганізми в іiі складі мають більш високу резистентність до дії антибактеріальних препаратів. Сполуки срібла перешкоджають зростанню і утворенню бактеріальних біоплівок. Численні клінічні дослідження крему Аргосульфан показали високу антибактеріальну активність препарату. Так, згідно з даними дослідження Є.В. Зінов’ єва і співавт., при лікуванні гнійних ран кремом Аргосульфан у пацієнтів 3 гнійно-некротичними формами синдрому діабетичної стопи частота нагноєння ран нижче на 15-19\%, ніж при використанні інших антибактеріальних мазей і антисептичного розчину [2, p. 893-800; 9, p. 32-37; 13, p. 45- 51; 66-70].

Основним завданням лікування ран у другій фазі регенерації ранового процесу - це прискорення процесу епітелізації і рубцювання ран. 3 цією метою використовують препарати рослинного походження - сік алое, обліпихи і шипшинова олія, каланхое. 3 огляду на це, слід враховувати високий відсоток ранових інфекційних ускладнень у хворих, розвиток резистентності у мікроорганізмів, зниження загальної і місцевої імунологічної реактивності організму, що вимагає подальшого вивчення рослинної сировини і розробки нових лікарських засобів даної фармакологічної групи. Раціональне поєднання рослинних препаратів з різними допоміжними речовинами, а також використання оптимальної технологічної схеми м'яких лікарських форм зовнішнього застосування, значно розширюють терапевтичні можливості фітопрепаратів для лікування і профілактики дерматологічних захворювань [5, р. 1196-1206; 11, p. 17-22].

Останнім часом при розробці лікарських засобів місцевої дії для лікування ран не зникає інтерес дослідників щодо застосування рослинної сировини, що має протимікробні, протизапальні і репаративні властивості (екстракти тополі китайської, листя горіха волоського, трави капусти 


\section{Chapter «Medical sciences»}

броколі, кори дуба тощо). Більш повно протимікробна, протизапальна і ранозагоювальна дія проявляється при використанні лікарських засобів природного походження. 3 цією метою в медичній практиці широко застосовуються препарати рослинного походження, що містять в своєму складі комплекс біологічно активних речовин (поліфенольний комплекс, алкалоїди, сапоніни, полісахариди, вітаміни, макро- і мікроелементи). Це мазі прополісу і календули, соки алое і каланхое, масло обліпихи, шипшини та звіробою. Для зазначених засобів характерне поєднання вираженої фармакологічної дії з мінімальним негативним впливом на організм, оскільки, будучи продуктами природного походження, вони легко їм засвоюються [6, p. 424-434].

Однією 3 перспективних груп рослин, які за даними літератури повинні проявляти антимікробні, протигрибкові, антивірусні властивості є рослини, що містять гідрохінон, нафтохінон і похідні антрахінону. Основними компонентами, що представляють ці групи речовин є: гідрохінон (в рослинах зустрічається у вигляді арбутину, метиларбутину i ін.); нафтохінон (в рослинах зустрічається у вигляді юглону, плюмбагину, лопачоли, шиконіну, хімафіліну, філохинону і ін.) і антрахінон (в рослинах зустрічається у вигляді алое-емодіну, емодінової кислоти, емодіну, хрізофанолу, алізарину, реїну, сенозидів, гіперицину та ін.).

На моделях ран і термічних опіків шкіри встановлено стимулюючий вплив лініменту з екстрактами ромашки аптечної, календули лікарської і деревію та мазі на основі екстракту цибулини часнику на репаративну регенерацію тканин. Доведено виражену антимікробну активність мазі з поліекстрактом квіток ромашки, що містять ефірне масло, стеарин, флавоноїди, дубильні речовини, полісахариди, мазі Субінак, що містить ефірну олію материнки дрібноквіткової на основі бентонітових глин, та лікарських засобів з сухими екстрактами льону посівного, просвірника і кропиви дводомної щодо ряду штамів стафілококу, а також спорової мікрофлори останніх.

\section{3. Обгрунтування вибору базового компоненту 3 протимікробною активністю та допоміжних інгредіснтів для створення нових мазевих композицій}

Створено ряд мазевих композицій, до складу яких входила активно діюча речовина - екстракт хмелю вуглекислотного (ЕХВ). ЕХВ отримують із шишок хмелю звичайного методом високоефективної рідин- 
ної хроматографії (BЕРХ). Принцип ВЕРХ полягає в розділенні компонентів суміші, який заснований на відмінності у рівноважному розподілі їх між двома фазами, які не змішуються між собою. Одна фаза рухлива, а інша нерухлива. Відмінною особливістю ВЕРХ $є$ використання високого тиску (до 400 бар) і дрібнозернистих сорбентів (3-5 мкм). Це дозволяє розділяти складні суміші речовин швидко та повно (середній час аналізу від 3 до 30 хв.)

Екстракт хмелю вуглекислотний - жовта або темно-зелена напіврідка сиропоподібна паста при кімнатній температурі. Основними біологічно активними речовинами, які обумовлюють фармакологічну активність екстракту хмелю вуглекислотного є: когумулон - 14,057\%; гумулон - адгумулон - 34,733\%; колупулон - 13,089\%; лупулон - адлупулон - 15,046\%.

Методом газової хроматографії встановлено якісний та кількісний біохімічний склад ЕХВ, до якого входять: ксантогумулон - 6,24\%; гумулон - адгумулон - 42,95\%; когумулон - $17,46 \%$; колупулон $10,67 \%$; лупулон - адлупулон - 11,78\%. 3 особливостями біохімічного складу ЕХВ пов'язана його протимікробна активність. В попередніх роботах продемонстрована висока протимікробна активність у складі гелю щодо грибів роду Candida та бактерій різних таксономічних груп: S. haemolyticus, S. pneumoniae, B. cereus, E. coli, P. aeruginosa, S. aureus, S. mutans, Acinetobacter spp., N. perflava, E. faecalis, K. oxytoca, K. pneumoniae, A. actinomycetemcomitans, P. intermedia, P. gingivalis, C. perfringens, та інших. Серед зазначених мікроорганізмів, які виявились чутливими до дії ЕХВ, до основних збудників інфекційно-запальних ускладнень ранового процесу належать: S. aureus, S. haemolyticus, E. coli, P. aeruginosa, C. perfringens, C. Albicans.

До складу мазевих композицій в якості допоміжних речовини, що впливають на фармакотерапевтичний ефект лікарського засобу. Як відомо, мазева основа, що складається 3 допоміжних речовин, впливає на стан, відповідну репараційну реакцію і перебіг патологічного процесу тієї ділянки шкіри і ранової поверхні, на яку її аплікують. Основа також вступає у складну взаємодію із введеною до іï складу базовою речовиною, підвищуючи або знижуючи їі стабільність, сприяючи або перешкоджаючи її вивільненню і всмоктуванню, підсилюючи або послаблюючи їі фармакологічну дію, а також значною мірою може впливати на прояв різноманітних побічних ефектів. Тобто, основа $\epsilon$ 


\section{Chapter «Medical sciences»}

зв'язуючою ланкою двох взаємореагуючих складових: основна діюча речовина - шкіра та ранова поверхня [3, p. 116-124].

Запорукою швидкого загоювання ран $є$ диференційний підхід до їх лікування в залежності від стадії ранового процесу та етіологічного чинника. Сприяє загоєнню ран підтримання належного рівня вологості регенеруючих тканин, для чого в теперішній час мазі виготовляють на гідрофільній основі [9, р. 32-37].

У I фазі ранового процесу при розробці мазей доцільно застосовувати гідрофільну поліетиленоксидну основу, яка має контрольовану дегідратуючу дію. Сучасні багатокомпонентні мазі в основному складаються з суміші двох видів ПЕО (найчастіше з масою 400 і 1500) в різних співвідношеннях (4:1-8:1). При нанесенні ПЕО-основи на рану вона залишається в більш поверхневих шарах, забезпечуючи сорбцію ранового ексудату. Здатність збільшувати силу антимікробної дії лікарських препаратів пов'язана з тим, що ПЕО зневоднюють мікробні клітини. При цьому ефективність дії протимікробних компонентів мазі підвищується в десятки разів. Використання ПЕО призводить до того, що протимікробний ефект настає навіть при дії тих речовин, до яких у мікроорганізмів раніше спостерігалась стійкість. Тому, серія експериментальних зразків мазевих композицій створювалась на поліетиленоксидній основі з різною концентрацією ПЕО 400 і ПЕО 1500 [6, p. 424-434].

У якості допоміжних речовин для одержання гомогенних мазевих композицій використовували поверхнево-активні речовини (ПАР, емульгатори) - полісорбітол 80 і емульгатор № 1, а також пролонгатор дії - пропіленгліколь. Як відомо, ці речовини можуть впливати на біологічну доступність лікарського засобу та його безпечність для організму.

При виконанні роботи створено 8 нових мазевих композицій, що відрізнялись за концентрацією ЕХВ (маса/маса, від 1 до 5\%) та якісним і кількісним складом допоміжних речовин (таблиця).

Експериментальна композиція зразка № 1 містить у своєму складі діючу речовину у концентрації $1,0 \%$ та в якості допоміжних речовин ПЕО 400 і ПЕО 1500. Композиції складів №№ 2 і 3 відрізняються від складу № 1 наявністю полісорбату 80 у концентрації 1,0\% і 2,0\% відповідно. До складів за №o 4 і 5, на відміну від складу № 1, було додатково внесено пропіленгліколь у концентрації по 10,0\% у кожний, і емульгатор № 1 у концентрації 3,0\% і 5,0\% відповідно. Композиція 
Khrystian Gennadiy, Torianyk Inna, Nevmrgitscky Vitaliy

Таблиця

Склад експериментальних мазевих композицій на основі ЕХВ

\begin{tabular}{|l|c|c|c|c|c|c|c|c|}
\hline \multirow{2}{*}{$\begin{array}{c}\text { Найменування } \\
\text { інгредіснтів }\end{array}$} & $\mathbf{1}$ & $\mathbf{2}$ & $\mathbf{3}$ & $\mathbf{4}$ & $\mathbf{5}$ & $\mathbf{6}$ & $\mathbf{7}$ & $\mathbf{8}$ \\
\hline ЕХВ & 1,5 & 1,5 & 1,5 & 1,5 & 1,5 & 1,5 & 3,0 & 5,0 \\
\hline Пропіленгліколь & - & - & - & 10,0 & 10,0 & 10,0 & - & - \\
\hline Полісорбат 80 & - & 1,0 & 3,0 & - & - & 1,0 & 1,0 & 1,0 \\
\hline Емульгатор № 1 & - & - & - & 3,0 & 5,0 & - & - & - \\
\hline ПЕО 400 & 79,0 & 72,0 & 70,0 & 56,0 & 56,0 & 60,0 & 70,0 & 68,0 \\
\hline ПЕО 1500 & 20,0 & 26,0 & 26,0 & 30,0 & 28,0 & 28,0 & 26,0 & 26,0 \\
\hline
\end{tabular}

зразка № 6 має склад аналогічний композиції зразка № 2, за винятком складової - пропіленгліколю, що було внесено до зазначеної композиції мазі у концентрації 10,0\%. Зразки мазі за №№ 7 і 8 також ідентичні складу № 2, але відрізняються від нього концентрацією діючою речовини $-3,0 \%$ і 5,0\% відповідно. Органолептичні характеристики мазі: однорідна; $\mathrm{pH}=6,0$ - 7,0; структурна вязкість 7,15-54,83 Па • с; осмотична активність 65\%; термостабільна; стабільна протягом 18 місяців (термін зберігання).

\section{4. Висновки}

На основі експериментальних (моделі ран і термічних опіків шкіри) та клінічних даних встановлено стимулюючий вплив мазевих препаратів на основі екстракту хмелю вуглекислотного на репаративну регенерацію тканин. Доведено, що за рахунок вмісту у зазначених препаратах ефірних масел, стеарину, флавоноїдів, дубильних речовин, полісахаридів зазначені мазі демонструють виражену антимікробну активність.

Для отримання позитивних результатів терапевтичного впливу саме у I-й фазі ранового процесу при розробці мазей доцільно застосовувати гідрофільну поліетиленоксидну основу з контрольованою дегідратуючою дією. 3 огляду на це, багатокомпонентні препарати повинні складатись із з сумішей двох або більше видів ПЕО (найчастіше з масою 400 і 1500) в різних співвідношеннях (4:1-8:1). Останнє обов'язковою мірою сприятиме ефективній сорбції ранового ексудату у разі безпосереднього нанесення ПЕО - основи на рану (з локалізація діючої речовини у поверхневих шарах шкіри). Таким чином, стає 


\section{Chapter «Medical sciences»}

досяжною можливість збільшувати силу антимікробної дії лікарських препаратів за рахунок ПЕО зневоднення мікробних клітин та підвищити ефективність дії протимікробних компонентів мазі на цілий порядок. Використання ПЕО призводить до того, що протимікробний ефект спостерігається навіть у разі впливу речовин, до яких мікроорганізми попередньо демонстрували виразну стійкість.

\section{Список літератури:}

1. Цимбалюк В.І., Ольховський В.О., Торяник І.І. Оцінка танатологічного профілю зони бойових дій (погляд судово-медичного експерта). Актуальні проблеми сучасної медицини. 2017. Том 17, випуск 3(59). С. 288-292.

2. Driver V.R., Lavery L.A., Reyzelman A.M. (2015). A clinical trial of Integra Template for diabetic foot ulcer treatment. Wound Repair Regen, 23(6), pp. 891-900.

3. Dryden M.S. (2014). New in antibiotic treatment for skin and soft tissue infection. Curr Opin Infect Dis, no. 27(2), pp. 116-124.

4. GeorgeHan, Roger, Ceilley (2017). Chronic Wound Healing: A Review of Current Management and Treatments. Adv Ther, no. 34(3), pp. 599-610.

5. Hill K.E., Malic C., McKee R., Rennison T., Harding K.G., Willians D.G., Thomas, D.G. (2010). An in vitro model of chronic wound biofilms to test wound dressings and assess antimicrobial susceptibilities. Journal of Antimicrobial Chemotherapy. no. 65(6), pp. 1195-1206.

6. Hori K., Matsumoto S. (2010). Bacterial adhesion: from mechanism to control. Biochemical Engineering Journal, no. 48(3), pp. 424-434.

7. Miller A.C., Rashid R.M., Falzon L., Elamin E.M., Zehtabchi S. (2012). Silver sulfadiazine for the treatment of partial-thickness burns and venous stasis ulcers. J Am Acad Dermatol, no. 66(5), pp. 159-165.

8. Paulson D.S. (2008). Biostatistics and microbiology: a survival manual/ D. S. Paulson // Springer Science \& Business Media. 100 p.

9. Sharmina Aftab, Md. Monowar Tarik, Dr. Mohammad Abdullah Yusuf (2014). Clinical and Microbiological Aspect of Wound Infection: A Review Update. Bangladesh Journal of Infectious Diseases, no. 1(2), pp. 32-37.

10. Wolcott R.D., Gontcharova V., Sun Y., Zischakau A., Dowd S.E. (2009). Bacterial diversity in surgical site infections: not just aerobic cocci any more. Journal of Wound Care, no. 18(8), pp. 317-323.

11. Gürgen M. (2014). Excess use of antibiotics in patients with non-healing ulcers. EWMA. Journal, no. 14(1), pp. 17-22.

12. International Wound Infection Institute (2016). Wound Infection in Clinical Practice. International Consensus. Wounds International, London, pp. 3-12.

13. Lipsky B.A., Aragón-Sánchez J., Diggle M. et all (2016). IWGDF guidance on the diagnosis and management of foot infections in persons with diabetes. Diabetes Metab Res. Rev 32 (Supp 1), pp. 45-74.

14. Wolcott R. (2015). Economic aspects of biofilm-based wound care in diabetic foot ulcers. J. Wound Care, no. 24(5), pp. 189-194. 
15. Tolkachjov S.N., Fahy A.S., Wetter D.A. et al. (2015). Postoperative pyoderma gangrenosum (PG): the Mayo Clinic experience of 20 years from 1994 through 2014. J. Am Acad Dermatol, no. 73. pp. 615-622.

16. Trostrup H., Thomsen K., Christophersen L.J. et al. (2013). Pseudomonas aeruginosa biofilm aggravates skin inflammatory response in BALB/c mice in a novel chronic wound model. Wound Repair and Regeneration, no. 21. pp. 292-299.

17. Seth A.K., Zhong A., Nguyen K.T. et al. (2014). Impact of a novel, antimicrobial dressing on in vivo, Pseudomonas aeruginosa wound biofilm: quantitative comparative analysis using a rabbit ear model. Wound Repair and Regeneration, no. 22(6), pp. 712-719.

18. Phillips P.L., Yang Q., Davis S. et al. (2015). Antimicrobial dressing efficacy against mature Pseudomonas aeruginosa biofilm on porcine skin explants. International Wound Journal, vol. 12, no. 4, pp. 469-483.

19. Ngo Q.D., Vickery K., Deva A.K. (2012). The effect of topical negative pressure on wound biofilms using an in vitro wound model. Wound Repair and Regeneration, vol. 20, no. 1, pp. 83-90.

20. Boles B.R., Horswill A.R. (2011). Staphylococcal biofilm disassembly. Trends in Microbiology, vol. 19, no. 9, pp. 449-455.

21. Lalliss S.J., Stinner D.J., Waterman S.M., Branstetter J.G., Masini B.D., Wenke J.C. (2010). Negative pressure wound therapy reduces pseudomonas wound contamination more than Staphylococcus aureus. Journal of Orthopaedic Trauma, vol. 24 , no. 9 , pp. 598-602.

\section{References:}

1. Tsymbaliuk V.I. (2017). Otsinka tanatolohichnoho profiliu zony boiovykh dii (pohliad sudovo-medychnoho eksperta). Aktualni problemy suchasnoi medytsyny, Tom 17, № 3(59). P. 288-292.

2. Driver V.R., Lavery L.A., Reyzelman A.M. (2015). A clinical trial of Integra Template for diabetic foot ulcer treatment. Wound Repair Regen, 23(6), pp. 891-900.

3. Dryden M.S. (2014). New in antibiotic treatment for skin and soft tissue infection. Curr Opin Infect Dis, no. 27(2), pp. 116-124.

4. GeorgeHan, Roger, Ceilley (2017). Chronic Wound Healing: A Review of Current Management and Treatments. Adv Ther, no. 34(3), pp. 599-610.

5. Hill K.E., Malic C., McKee R., Rennison T., Harding K.G., Willians D.G., Thomas, D.G. (2010). An in vitro model of chronic wound biofilms to test wound dressings and assess antimicrobial susceptibilities. Journal of Antimicrobial Chemotherapy. no. 65(6), pp. 1195-1206.

6. Hori K., Matsumoto S. (2010). Bacterial adhesion: from mechanism to control. Biochemical Engineering Journal, no. 48(3), pp. 424-434.

7. Miller A.C., Rashid R.M., Falzon L., Elamin E.M., Zehtabchi S. (2012). Silver sulfadiazine for the treatment of partial-thickness burns and venous stasis ulcers. J Am Acad Dermatol, no. 66(5), pp. 159-165.

8. Paulson D.S. (2008). Biostatistics and microbiology: a survival manual / D.S. Paulson // Springer Science \& Business Media. 100 p. 
9. Sharmina Aftab, Md. Monowar Tarik, Dr. Mohammad Abdullah Yusuf (2014). Clinical and Microbiological Aspect of Wound Infection: A Review Update. Bangladesh Journal of Infectious Diseases, no. 1(2), pp. 32-37.

10. Wolcott R.D., Gontcharova V., Sun Y., Zischakau A., Dowd S.E. (2009). Bacterial diversity in surgical site infections: not just aerobic cocci any more. Journal of Wound Care, no. 18(8), pp. 317-323.

11. Gürgen M. (2014). Excess use of antibiotics in patients with non-healing ulcers. EWMA. Journal, no. 14(1), pp. 17-22.

12. International Wound Infection Institute (2016). Wound Infection in Clinical Practice. International Consensus. Wounds International, London, pp. 3-12.

13. Lipsky B.A., Aragón-Sánchez J., Diggle M. et all (2016). IWGDF guidance on the diagnosis and management of foot infections in persons with diabetes. Diabetes Metab Res. Rev 32 (Supp 1), pp. 45-74.

14. Wolcott R. (2015). Economic aspects of biofilm-based wound care in diabetic foot ulcers. J. Wound Care, no. 24(5), pp. 189-194.

15. Tolkachjov S.N., Fahy A.S., Wetter D.A. et al. (2015). Postoperative pyoderma gangrenosum (PG): the Mayo Clinic experience of 20 years from 1994 through 2014. J. Am Acad Dermatol, no. 73. pp. 615-622.

16. Trostrup H., Thomsen K., Christophersen L.J. et al. (2013). Pseudomonas aeruginosa biofilm aggravates skin inflammatory response in BALB/c mice in a novel chronic wound model. Wound Repair and Regeneration, no. 21. pp. 292-299.

17. Seth A.K., Zhong A., Nguyen K.T. et al. (2014). Impact of a novel, antimicrobial dressing on in vivo, Pseudomonas aeruginosa wound biofilm: quantitative comparative analysis using a rabbit ear model. Wound Repair and Regeneration, no. 22(6). pp. 712-719.

18. Phillips P.L., Yang Q., Davis S. et al. (2015). Antimicrobial dressing efficacy against mature Pseudomonas aeruginosa biofilm on porcine skin explants. International Wound Journal, vol. 12, no. 4, pp. 469-483.

19. Ngo Q.D., Vickery K., Deva A.K. (2012). The effect of topical negative pressure on wound biofilms using an in vitro wound model. Wound Repair and Regeneration, vol. 20, no. 1, pp. 83-90.

20. Boles B.R., Horswill A.R. (2011). Staphylococcal biofilm disassembly. Trends in Microbiology, vol. 19, no. 9, pp. 449-455.

21. Lalliss S.J., Stinner D.J., Waterman S.M., Branstetter J.G., Masini B.D., Wenke J.C. (2010). Negative pressure wound therapy reduces pseudomonas wound contamination more than Staphylococcus aureus. Journal of Orthopaedic Trauma, vol. 24 , no. 9 , pp. 598-602. 